\title{
Recreational activities impact on the amount and characteristics of woody debris in the Fandoghlou forests, Northwestern Iran
}

\author{
Farshad Keivan Behjou and Kiomars Sefidi*
}

Behjou, F.K., Sefidi, K. 2015. Recreational activities impact on the amount and characteristics of woody debris in the Fandoghlou forests, Northwestern Iran. - Forestry Studies | Metsanduslikud Uurimused 62, 5-13. ISSN 1406-9954. Journal homepage: http://mi.emu.ee/forestry.studies

\begin{abstract}
In this research, the volume and composition of woody debris (WD) were inventoried by line intersect sampling (LIS) in recreational and conservative parts of Fandoughlou forests in Northwestern Iran. Based on the pre-study qualitative assessments of WD properties, 60 transects in conserved part including 60 ha tract and 60 transects in recreational part including 60 ha and 60 transects were set up for WD survey. In each area, a systematic series of sampling points was located in the inventory of WD. At each sampling point, we performed line-intersect sampling (LIS) with a line length of $100 \mathrm{~m}$ with random orientation of sample lines. Estimates of the total volume of WD across recreational and conservative parts of the forest ranged from $0.70 \mathrm{~m}^{3} \mathrm{ha}^{-1}$ to $1.49 \mathrm{~m}^{3} \mathrm{ha}^{-1}$. The results of independent $t$-test indicated that the amount of CWD and FWD in conserved part is significantly higher than CWD and FWD in recreational part $\left(\mathrm{t}_{4,0.05}=4.26, p=0.013 ; \mathrm{t}_{4,0.05}=2.69, p=0.05\right)$. The number of tree species of CWD composition was higher in conserved area, more than 5 species including (hazel, beech, hornbeam, oak, maple, and other species). In the conserved part, CWD in highly-decayed classes accounted for $75 \%$ of total CWD volumes, but in the recreational division, CWD in the early decayed classes accounted for $79 \%$ of total WD volumes. Our results suggest preserving the current conserved forests and maintaining the structural and functional integrity of WD.
\end{abstract}

Key words: woody debris, line intersects method, recreational part, conserved area, Fandoghlou forests.

Authors' address: Faculty of Agricultural Technology and Natural Resources, University of Mohaghegh Ardabili, Ardabil, Iran, *e-mail: kiomarssefidi@gmail.com

\section{Introduction}

Woody debris (WD), including coarse woody debris (CWD) and fine woody debris (FWD), can be an essential structure and functional component of many forest ecosystems (Muller \& Liu, 1991; McCarthy \& Bailey, 1994; Lipan et al., 2008). WD plays a key role in many aspects of ecosystem functioning (Harmon et al., 1986; Sefidi \& Mohadjer, 2010; Zolfaghari, 2005; Sefidi et al., 2013), both in aquatic systems and terrestrial, including habitat for wildlife and fungi, nursery site for seedling establishment, nutrient cycling and soil stability. The classification of fallen dead woods based on size reflects a difference in the ecological role of CWD and FWD. As examples, FWD had significantly more species of ascomycetes and basidiomycetes per unit wood volume than CWD in the same forest (Nordén et al., 2004) and FWD experienced decay rates that were twice as rapid as CWD (Müller-Using \& Bartsch, 2009) and even 
CWD different sizes can provide a diversity of microsites and different suites of species. In recent decades, forestry shifted towards a more near-to-nature approach to forest management with the aim of developing forest stands that are comparable to natural ones in so far as structure, composition and regeneration processes are concerned (Wolynski, 1998; Dotta \& Motta, 2000). In this perspective, silvicultural practices may be modified with the intent of creating or maintaining an adequate stock of WD and of promoting WD structure similar to that found in unmanaged forests (Siitonen et al., 2000; Ranius \& Kindvall, 2004; Behjou \& Mollabashi, 2013).

The classification based on size reflects a difference in the ecological role of CWD and FWD. As examples, FWD had significantly more species of ascomycetes and basidiomycetes per unit wood volume than CWD in the same forest. Kurbanov \& Vorobev (2008) studied spatial distribution of CWD in pine forests of Trans Volga region in Russia and the results of study proved that CWD distribution have tendency toward spatial grouping (clustering) and stocks along with increase in stand age. Motta et al. (2006) estimated the amount of CWD in Valbona forest reserve, Italian Alps. The results of study indicated that the mean volume of CWD in the study area was $23.4 \mathrm{~m}^{3}$ ha $^{-1}$ ranging in the sampling plots between 0.0 and $89.3 \mathrm{~m}^{3} \mathrm{ha}^{-1}$. Sefidi (2007) calculated the amount of CWD in Caspian managed forests. The results of his study indicated that the range of CWD in the study area ranged from 5.80 to $8.40 \mathrm{~m}^{3} \mathrm{ha}^{-1}$. Lipan et al. (2008) estimated WD stocks in secondary and primary forests in the subtropical Ailao Mountains in China. The results indicated that the ratios of CWD to FWD were low in the secondary forest (about 1-4) but high in the primary forest (about 15). Sefidi \& Mohadjer (2010) studied the characteristics of CWD in different successional stages in Caspian forests. The results of study showed that the volume of CWD followed the general "U-shaped" temporal trend: the highest in the late successional forest (51.25 $\left.\mathrm{m}^{3} \mathrm{ha}^{-1}\right)$, lowest in the middle successional forest $\left(25.95 \mathrm{~m}^{3} \mathrm{ha}^{-1}\right)$ and intermediate in the early successional forest $\left(37.05 \mathrm{~m}^{3} \mathrm{ha}^{-1}\right)$. Behjou \& Mollabashi (2013) assessed CWD following selective logging in Caspian forests. The results of study indicated that line intersect sampling is the best method for measuring CWD (high efficiency and high accuracy). They estimated the amount of CWD is $6.46 \mathrm{~m}^{3} \mathrm{ha}^{-1}$ using line intersects sampling.

Sefidi et al. (2013) studied the amount of CWD and FWD within semi virgin beech stands in the north of Iran. CWD had an average volume of $15 \mathrm{~m}^{3} \mathrm{ha}^{-1}$ and FWD had an average of $10 \mathrm{~m}^{3} \mathrm{ha}^{-1}$. This study focuses on comparing the amount of WD in recreational and conserved parts of the Fandoghlou forest ecosystem. This forest located in the northwest of Iran. Some of Fandoghlou forest area conserved from manipulations and created unique opportunity to study forest structure in early successional stage. In contrasts presence of rural community and gathering fuel and recreational activities (picnic sites and firewood gathering) highly affect vegetation structure in this area. WD amount as feature of forest stand structure changed in this area. This study aimed to detect recreational activities impact on the amount and characteristics of WD in Fandoghlou forests. The aim of this study was to examine the amount and the quality of the WD in recreational and conserved parts in hazel dominated forest sites in Fandoghlou region. Our objectives are: (a) to characterize the amount of WD in the forest, (b) to delineate the WD type and decay class and (c) to analyze the role of recreational activity on the amount and quality of WD.

\section{Material and Methods}

\section{Study site}

Sampling WD was conducted in the Fandoghlou forests, a 120 ha tract of 
northwestern hardwood (half of it, recreational forest and half of it conserved) located in Ardabil province during spring 2011. Fandoghlou forests with an area around 1000 ha are located on the Northwestern of Iran. The research was conducted on a hazel dominated forest in Fandoghlou in Ardabil, Iran ( $38^{\circ} 24^{\prime} \mathrm{N}, 48^{\circ}$ $\left.35^{\prime} \mathrm{E}\right)$ with the area of 59 ha. The stand was dominated by hazel (Corylus sp.), hornbeam (Carpinus betulus L.) and beech (Fagus orientalis Lipsky). Average annual rainfall is 430 $\mathrm{mm}$, and the average annual temperature is $10^{\circ} \mathrm{C}$. The study site is a recreational forest with an altitudinal range from about 1320 to $1600 \mathrm{~m}$. The Fandoghlou forests have been traditionally exploited in various ways to maximize economic and social benefits: recreational use has been combined with other functions such as protection. Recreational uses and conserved have existed side-byside for decades and only in recent decade recreational areas have been separated from conserved forests (Yousefpour et al., 2005).

We detected 3 separate places in the field for recreational and conserved parts. Forest composition there is typical of the northwestern hardwood type in Iran with mature stand dominated by hazel, beech, maple (Acer velutinum Boiss.) and hornbeam tree species. Two parts were used for this study: under and without recreational activities (Table 1). All selected area has same stand structure and composition. The conserved area was protected for around fifty years. At all sites forests were dominated by hazel, characteristic of approximately
$80 \%$ of Fandoghlou forests. In each study area plots $(10 \times 10 \mathrm{~m})$ and lines $(100 \mathrm{~m})$ were selected with systematic random sampling for assessing FWD and CWD, respectively.

\section{Measurement of the volume and composi- tion of WD}

The most widely used methods for sampling FWD and CWD are fixed plot sampling (Lipan et al., 2008) and the line-intersect method (Warren \& Olsen, 1964; Behjou \& Mollabashi, 2013) where the diameter of CWD in line intersect sampling is measured at the point of intersection along a transect of a given length but no width. Lengths and diameters were taken at the edge of the plot boundary if the log extended outside of the plot.

Based on the pre-study qualitative assessments of WD properties, 60 transects in conserved part including 60 ha tract and 60 transects in recreational part including 60 ha and 60 transects were set up for WD survey. In each area, a systematic series of sampling points was located in the inventory of WD. At each sampling point, we performed line-intersect sampling (LIS) with a line length of $100 \mathrm{~m}$ with random orientation of sample lines. For LIS, we followed slope correction procedure outline by Ståhl et al. (2002).

Volume of individual pieces per hectare was calculated using the formula (1).

Table 1. A description of the study area and inventory methods.

\begin{tabular}{lccccc}
\hline $\begin{array}{l}\text { Management } \\
\text { history }\end{array}$ & $\begin{array}{c}\text { Area } \\
\text { (ha) }\end{array}$ & Plot type & $\begin{array}{c}\text { Plot size, } \\
\text { transect length } \\
(\mathrm{m})\end{array}$ & $\begin{array}{c}\text { Number of } \\
\text { transects, } \\
\text { plots }\end{array}$ & Forest type \\
\hline Conserved & 15 & Transect and plot & $10 \times 10,100$ & 15,15 & Mixed hazel \\
& 22 & Transect and plot & $10 \times 10,100$ & 22,22 & Mixed hazel \\
& 23 & Transect and plot & $10 \times 10,100$ & 23,23 & Mixed hazel \\
\hline Recreation & 19 & Transect and plot & $10 \times 10,100$ & 19,19 & Hazel \\
& 24 & Transect and plot & $10 \times 10,100$ & 24,24 & Hazel \\
& 17 & Transect and plot & $10 \times 10,100$ & 17,17 & Hazel \\
\hline
\end{tabular}


$Y_{i}\left(\mathrm{~m}^{3} \mathrm{ha}^{-1}\right)=\frac{\pi^{2}}{8 L} \times \sum_{j=1}^{m_{j}} \frac{d_{i j}^{2}}{\cos \lambda_{i j}}$

where $\pi$ - consonant amount (3.14), $L$ length of line transect $(m), d_{i j}$ - diameter of CWD piece $j$ crossed by line transect $i(\mathrm{~m})$, $\lambda_{i j}$ - acute angle from the horizontal of CWD piece $j$ crossed by line transect $i$ (degrees), $Y_{i}$ - volume per hectare based on line transects $i\left(\mathrm{~m}^{3} \mathrm{ha}^{-1}\right)$.

In each transect, all species of woody residues with a large-end diameter $\geq 10 \mathrm{~cm}$ (CWD) were recorded separately. The length, small-and large-end diameter of all pieces of logs, stumps, and large branches were measured and recorded. On the hand, tree species, basal diameter, diameter at breast height (DBH) and decay stages were recorded for all the logs standing dead trees (snags) and branches on each transect. Also, FWD was defined all WD fragments with a diameter of 2.5$10 \mathrm{~cm}$ into it, and a length greater than $10 \mathrm{~cm}$ (Lipan et al., 2008). For FWD investigation, at the end point of each transect a $2 \times 2 \mathrm{~m}$ plot was established. For modified decay classification system and class definition, a new modified indirect measurement developed by Rouvinen et al. (2002) was used in the field. The main contents are as follows: (1) the dead wood dies within 1-2 years, and the cambium is still fresh when investigation, (2) the cambium begins to compose, and the knife blade penetrates a few millimeters into it, (3) the knife blade penetrates 1-1.5 cm into it, (4) the knife blade penetrates $2-3 \mathrm{~cm}$ into it, and (5) the knife blade penetrates all the way.

\section{Statistical analysis}

To determine whether the volume of CWD affected by recreational activities independent $t$-test was used. Normality and homogeneity of variance of the residuals were tested and data were log-transformed if the homogeneity of variance was not met. All statistical tests were considered significant at the $p<0.05$ level (Zar, 1999).

\section{Results}

\section{Total amount of WD}

Estimates for volume per hectare are given for CWD and FWD in each study area in Tables 2, respectively. The low volume of the total amount of CWD was in recreational part (Table 2). The results of independent $t$-test indicate that the amounts of CWD in conserved $(1.24 \pm 0.12)$ part are significantly higher than CWD in recreational part $(0.62 \pm 0.08)\left(\mathrm{t}_{4,0.05}=4.26\right.$, $p=0.013$ ) (Table 3 ). Also, the results of independent $t$-test revealed that the amounts of FWD in conserved part $(0.25 \pm$ 0.06) are significantly higher than FWD in recreational part $(0.08 \pm 0.02),\left(t_{4,0.05}=2.69\right.$, $p=0.04$ ) (Table 3). Also, the ratio of CWD: FWD in conserved part of the forest is 5:1, but this ratio in recreational part of the forest is $8: 1$.

Table 2. The volume of coarse and fine woody debris $\left(\mathrm{m}^{3} \mathrm{ha}^{-1}\right)$ in the Fandoghlou Forests, northwest of Iran.

\begin{tabular}{|c|c|c|c|c|c|c|c|}
\hline \multirow{2}{*}{$\begin{array}{l}\text { Management } \\
\text { history }\end{array}$} & \multicolumn{3}{|c|}{ CWD } & \multicolumn{3}{|r|}{ FWD } & \multirow[t]{2}{*}{ Total } \\
\hline & Study sites & Snags & Stumps & Logs & Branches & Small twigs & \\
\hline \multirow[t]{3}{*}{ Conserved } & 1 & 0.06 & 0.09 & 0.44 & 0.49 & 0.14 & 1.22 \\
\hline & 2 & 0.07 & 0.08 & 0.49 & 0.52 & 0.26 & 1.42 \\
\hline & 3 & 0.11 & 0.11 & 0.53 & 0.73 & 0.34 & 1.82 \\
\hline \multirow[t]{3}{*}{ Recreational } & 1 & 0.00 & 0.05 & 0.19 & 0.23 & 0.05 & 0.52 \\
\hline & 2 & 0.02 & 0.09 & 0.22 & 0.32 & 0.09 & 0.74 \\
\hline & 3 & 0.04 & 0.09 & 0.28 & 0.33 & 0.11 & 0.85 \\
\hline
\end{tabular}




\section{Species composition of CWD}

The amount of species composition of CWD found in two management treatments (conserved and recreational parts) varied. The amount of tree species for CWD composition was the highest in conserved area, more than 5 species including hazel, beech, hornbeam, oak, maple, and other species, also hazel, beech and hornbeam accounted for $84 \%$ of the total volume of CWD, in contrast in the mixed hazel stands had the greatest volume of CWD volume, reaching $0.61 \mathrm{~m}^{3} \mathrm{ha}^{-1}$, and the next comes 16.91 $\mathrm{m}^{3}$ ha $^{-1}$ for beech (Table 4). The amount of hazel and beech in CWD composition in recreational part (98\%) is higher than the amount of hazel and beech in CWD composition in conserved part $(68 \%)$ (Table 4).

\section{Decay classes distribution of WD}

The distribution of CWD in different decay classes varied among the conserved and recreational forests (Table 5). In the conserved part, CWD in decay classes 1, 2 accounted for $25 \%$ of total CWD volumes, but CWD in decay classes 3, 4 , and 5 accounted for $75 \%$ of total CWD volumes. In the recreational part, CWD in decay classes 1 and 2 accounted for $100 \%$ of total CWD volumes, but not observed any CWD in decay classes 3, 4 , and 5 accounted. The volume of CWD in class 1 was significantly higher in recreational area $\left(t_{4,0.05}=9.36\right.$, $p=0.003$ ) (Figure 1).

Table 3. The results of ANOVA and Tukey test, and independent $t$-test in CWD, FWD and total WD.

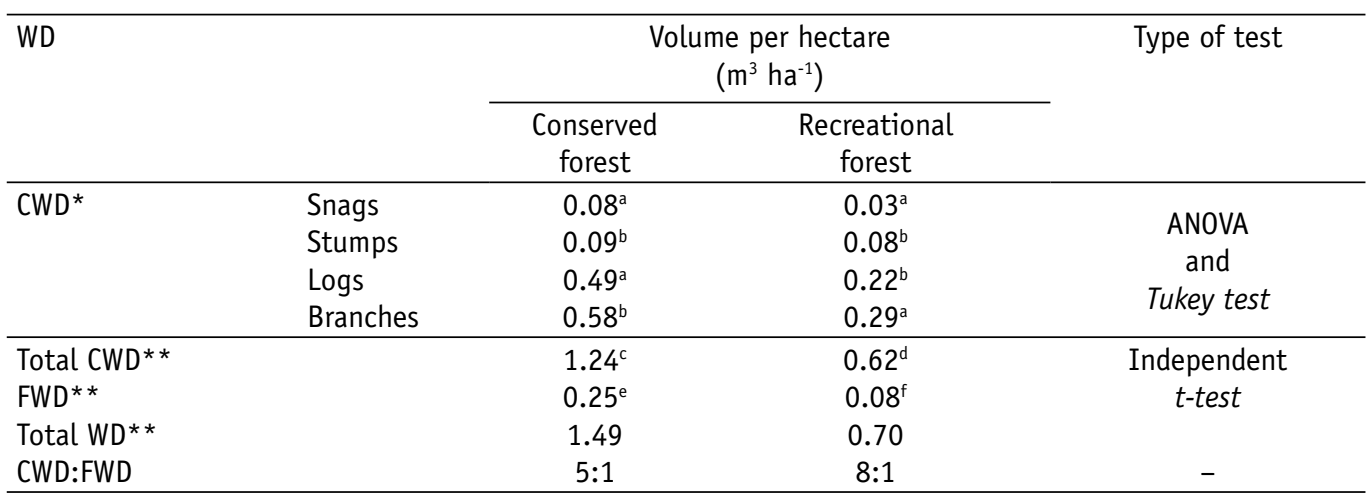

* Among rows of one column

** Between two columns

Table 4. Species composition of CWD in two management treatments.

\begin{tabular}{llcccccc}
\hline Management & Variable & \multicolumn{7}{c}{ Type of species } \\
\cline { 2 - 8 } history & Hazel & Beech & Hornbeam & Oak & Maple & $\begin{array}{c}\text { Other } \\
\text { species }\end{array}$ \\
\hline Conserved & Volume $\left(\mathrm{m}^{3} \mathrm{ha}^{-1}\right)$ & 0.61 & 0.24 & 0.20 & 0.07 & 0.02 & 0.10 \\
forest & Percent $(\%)$ & 49 & 19 & 16 & 5 & 2 & 8 \\
\hline $\begin{array}{l}\text { Recreational } \\
\text { forests }\end{array}$ & Volume $\left(\mathrm{m}^{3}\right.$ ha $\left.^{-1}\right)$ & 0.58 & 0.03 & 0.01 & - & - & - \\
\hline
\end{tabular}


Table 5. Comparison of CWD (more than $10 \mathrm{~cm}$ in diameter) amount in Caspian forest.

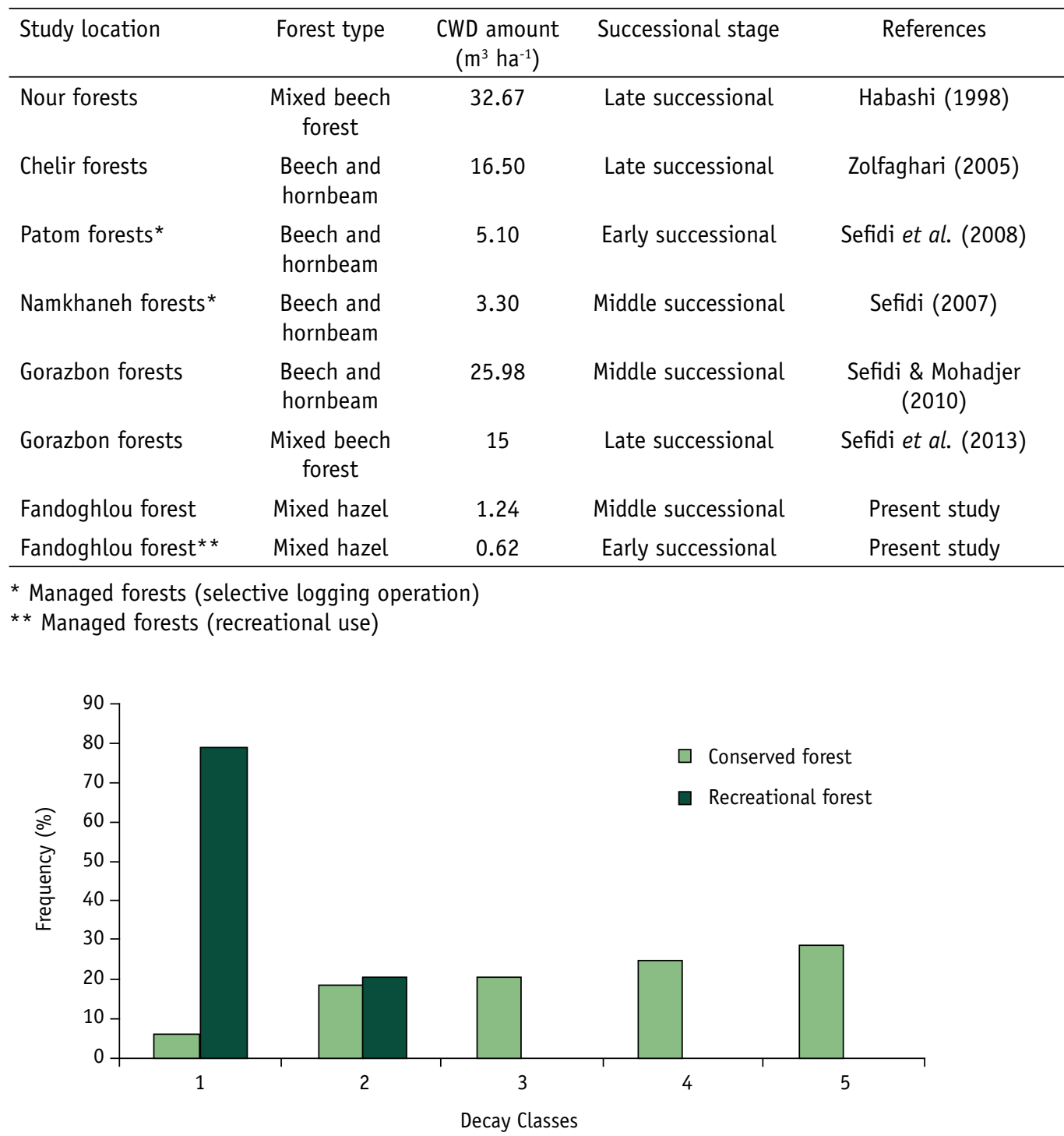

Figure 1. Relative frequency of total amount of CWD between two management treatments.

\section{Discussion and Conclusion}

In the present study, line-intersect and fixed area plot sampling method was applied to estimating the total volume of WD in managed and unmanaged forest stands. Results showed differences in amount of WD in recreational and conserved area. Some researchers have proved that the amounts of CWD in unmanaged forest are higher than managed one (Motta et al., 2006). In our study, it was obviously different in the amount of WD from recreational forest to conserved forest. Some researchers have found that CWD is more in unmanaged stands compared to managed stands 
(with logging operation), on the other hand, FWD was found to be less in unmanaged stands compared to managed stands (Sefidi \& Mohadjer, 2010). In the same study in mixed beech stands in the north of Iran Sefidi et al. (2013) found 15 and $10 \mathrm{~m}^{3} \mathrm{ha}^{-1}$ for CWD and FWD, respectively. Three dominant influences on CWD volume are stand age, stand management and decomposition rate (Meyer et al., 2003; Christensen et al., 2005). Forest management histories can have substantial impacts on the production and yield of WD in terrestrial ecosystems (Radtke et al., 2009; Sefidi et al., 2013). The CWD amount of $1.24 \mathrm{~m}^{3} \mathrm{ha}^{-1}$ in the conserved stands is lower than that of some studies (Habashi, 1998; Sefidi \& Mohadjer, 2010), the main reason of these high differences is due to that Fandoghlou forest is coppice forest and dimension of forest trees is smaller in comparison to the beech stands in the north of Iran. Also the amount of CWD calculated $0.62 \mathrm{~m}^{3} \mathrm{ha}^{-1}$ in the recreational stands is lower than that of some studies (Sefidi, 2007) (Table 5), which can be caused by differences in climate and presence of rural communities near to the Fandoghlou forest. Meanwhile gathering fuel from dead branches in last decades cane be consider as one of main reasons for decrease WD amount in recreational area.

The constant removal of WD for recreational purposes such as firewood caused to reduction of WD in forest ecosystems (Hegetschweiler et al., 2009). WD collecting for building fires is exclusively FWD (diameter 5-10 cm; Kruys \& Jonsson, 1999) and very fine woody debris (diameter < $5 \mathrm{~cm}$; Kueffer \& Senn-Irlet, 2005).

Species composition of CWD is substantially different among the recreational and conserved parts in the region. The CWD composition within the conserved stands comes from different percentage compared to recreational stands. WD species in conserved stands are mainly comprised of more than 5 species including hazel, beech, hornbeam, oak, maple, and other species but WD species in recreational stands are mainly comprised of only one species including hazel and hornbeam (93\%). On the other hand, the high decayed component of CWD has increased in conserved stands compared to recreational part (Lipan et al., 2008).

In conclusion, the amounts of WD were significantly different from conserved to recreational parts of the forest. Our results proved that the residual accumulation of WD from the conserved stands are low, and the current accumulation of higher stocks of WD, need a long time in the recreational parts under recreational activities. Recovering time for WD structure and composition similar to unmanaged stands may exceed several centuries, so it is very important to preserve the current conserved forests (protected forests) and maintain the structural and functional integrity of WD. These results can serve as a basis for further research on WD in the regional scale and may be useful in developing guidelines for Fandoghlou forest management aimed at biodiversity management.

Unfortunately, traditional management methods in Fandoghlou forests include harvesting CWD from the forests (Sefidi $\&$ Mohadjer, 2010), that need to refine this false decision. The results of the study suggest that using of standing and fallen materials from recreational parts will lead to a sharp drop in CWD. Reductions in the volume of CWD in forests may have negative consequences for populations of endemic, understory bird species (Yan et al., 2007; Sefidi \& Mohadjer, 2010).

Acknowledgments. This project was funded by University of Mohaghegh Ardabili. We would like to thank this organization for financial support to collect field data. 


\section{References}

Behjou, F.K., Mollabashi, O.G. 2013. Assessment of coarse woody debris following selective logging in Caspian forests: implications for conserved and management. - Journal of Forest Science, 59, 117-124.

Christensen, M.K., Hahn, E.P., Mountford, P., Ódor, T., Standovár, D., Rozenbergar, J., Diaci, S., Wijdeven, S., Meyer, P., Winter, S., Vrska, T. 2005. Dead wood in European beech (Fagus sylvatica) forest reserves. - Forest Ecology and Management, 210, 267-282.

Dotta, A., Motta, R. 2000. Mountain conifer silviculture in Piedmont (Italy). (Boschi di conifere montani. Indirizzi selvicolturali. Regione Piemonte, Blu Edizioni, Peveragno (CN)). 192 pp. (In Italian).

Habashi, H. 1998. Study of ecological and silvicultural importance of dead trees in Nour forests. MSc Thesis, Faculty of Natural Resources, University of Tarbiat Modarres. 241pp.

Harmon, M.E., Franklin, J.F., Swanson, F.J., Sollins, P., Gregory, S.V., Lattin, J.D., Anderson, N.H., Cline, S.P., Aumen, N.G., Sedell, J.R., Lienkaemper, G.W., Cromack, K. (jr), Cummins, K.W. 1986. Ecology of coarse woody debris in temperate ecosystems. - Advances in Ecological Research, 154, 133-302.

Hegetschweiler, K.T., van Loon, N., Ryser, A., Rusterholz, H.-P., Baur, B. 2009. Effects of fire place use on forest vegetation and amount of woody debris in suburban forests in northwestern Switzerland. - Environmental Management, 43, 299-310.

Kruys, N., Jonsson, B.G. 1999. Fine woody debris is important for species richness on logs in managed boreal spruce forests of northern Sweden. Canadian Journal of Forest Research, 29, 12951299.

Kueffer, N., Senn-Irlet, B. 2005. Influence of forest management on the species richness and composition of wood-inhabiting basidiomycetes in Swiss forests. - Biodiversity and Conservation, 14, 2419-2435.

Kurbanov, E.A., Vorobev, O.N. 2008. Spatial distribution of coarse woody debris in pine forests of the Marii EI Transvolga region. - Russian Journal of Ecology, 39, 92-98.

Lipan, Y., Wenyao, L., Whenzhang, M. 2008. Woody debris stocks in different secondary and primary forests in subtropical Ailao Mountains. Southwest Journal of China, 2, 805-812.

McCarthy, B.C., Bailey, R.R. 1994. Distribution and abundance of coarse woody debris in a Managed forest landscape of the central Appalachians. Canadian Journal of Forest Research, 24, 13171329.

Meyer, P., Tabaku, V., von Lupke, B. 2003. Structural characteristics of Albanian beech (Fagus sylvatica L.) virgin forests - deductions for semi-natural forestry. - Forstwissenschaftliches Centralblatt, 122, 47-58.

Motta, R., Berretti, R., Lingua, E., Piussi, P. 2006. Coarse woody debris, forest structure and regeneration in the Valona Forest Reserve, Paneveggio, Italian Alps. - Forest Ecology and Management, 235, 155-163.

Muller, R.N., Liu, Y. 1991. Coarse wood debris in an old-growth deciduous forest on the Cumberland plateau, southeastern Kentucky. - Canadian Journal of Forest Research, 21, 1567-1572.

Müller-Using, S., Bartsch, N. 2009. Decay dynamic of coarse and fine woody debris of a beech (Fagus sylvatica L.) forest in Central Germany. - European Journal of Forest Research, 128, 287-296.

Nordén, B., Ryberg, M., Götmark, F., Olausson, B. 2004. Relative importance of coarse and fine woody debris for the diversity of wood-inhabiting fungi in temperate broadleaf forests. - Biological Conservation, 117, 1-10.

Radtke, P.J., Amateis, R.L., Prisley, S.P., Copenheaver, C.A., Chojnacky, D.C., Pittman, J.R., Burkhart, H.E. 2009. Modeling production and decay of coarse woody debris in loblolly pine plantations. Forest Ecology and Management, 257, 790-799.

Ranius, T., Kindvall, O. 2004. Modelling the amount of coarse woody debris produced by the new biodiversity-oriented silvicultural practices in Sweden. Biological Conservation, 119, 51-59.

Rouvinen, S., Kuuluvainen, T., Karjanainen, L. 2002. Coarse woody debris in old Pinus sylvestris dominated forests along a geographic and human impact gradient in boreal Fennoscandia. - Canadian Journal of Forest Research, 32, 2184-2200.

Sefidi, K. 2007. Investigation on dead trees effects on natural regeneration of oriental beech and hornbeam in a mixed beech forest. - Iranian Journal of Forest and Poplar Research, 14, 238-245.

Sefidi, K., Mohadjer, M.M.R. 2010. Characteristics of coarse woody debris in natural beech (Fagus orientalis) forests. - Journal of Forest Science, 56, 7-17.

Sefidi, K., Mohadjer, M.M.R., Etemad, V., Zobeiri, M. 2008. Dead beech trees effect on establishment of natural regeneration of beech and hornbeam in a mixed beech forest. - Journal of Iranian Forest and Poplar Research, 15(4), 327-374. (In Persian).

Sefidi, K., Mohadjer, M.M.R., Mosandl, R., Copenheaver, C.A. 2013. Coarse and fine woody debris in mature oriental beech (Fagus orientalis Lipsky) forests of Northern Iran. - Natural Areas Journal, 31(1), 255-248.

Siitonen, J., Martikainen, P., Punttila, P., Rauh, J. 2000. Coarse woody debris and stand characteristics in mature managed and old-growth boreal mesic forests in Southern Finland. - Forest Ecology and Management, 128, 211-225.

Ståhl, G., Gove, J.H., William, M.S., Ducey, M.J. 2010. Critical length sampling: a method to estimate the volume of downed coarse woody debris. European Journal of Forest Research, 129, 9931000. 
Warren, W.G., Olsen, P.F. 1964. A line intersects technique for assuming logging waste. - Forest Science, 10, 267-276.

Wolynski, A. 1998. Historical evolution of natural forestry. (Evoluzione storica della selvicoltura naturalistica). - Sherwood, 40, 5-11. (In Italian).

Yan, E.R., Wang, X., Huang, H., Zeng, F., Gong, L. 2007. Long-lasting legacy of forest succession and forest management: characteristics of coarse woody debris in an evergreen broad-leaved forest of Eastern China. - Forest Ecology and Management, 252, 98-107.
Yousefpour, R., Mohadjer, M.M.R., Saghebtalebi, Kh. 2005. Study of oriental beech succession in Fandoghlu forest. - Iranian Journal of Natural Resources, 57(4), 703-714.

Zar, J.H. 1999. Biostatistical Analysis. Upper Saddle River Prentice-Hall.

Zolfaghari, A. 2005. Investigation of ecological roles of dead tree in Chelir forests. MSc Thesis. Faculty of Natural Resources. University of Tehran.

Received February 27, 2015, revised April 10, 2015, accepted May 30, 2015 